$$
\text { Emerald International Journal of }
$$

The securitization of residential rental revenue streams in Europe

\begin{tabular}{|r|l|}
\hline Journal: & International Journal of Housing Markets and Analysis \\
\hline Manuscript ID & IJHMA-07-2016-0057.R1 \\
\hline Manuscript Type: & Research Paper \\
\hline Keywords: & $\begin{array}{l}\text { Property Securitization, REO-to-Rental Securitization, Non-Performance } \\
\text { Loans, Alternative Finance, Property Finance, Real Estate Investment }\end{array}$ \\
\hline \multicolumn{2}{|l}{} \\
\hline
\end{tabular}

SCHOLARONE ${ }^{\text {m }}$

Manuscripts 


\title{
The Securitization of Residential Rental Revenue Streams in Europe
}

\author{
Jaume Roig Hernando \\ Doctor in Business Administration \\ Department of Management, Polytechnic University of Catalonia
}

20

21

22

23

24

25

26

27

28

29

30

31

32

33

34

35

36

37

38

39

40

41

42

43

44

45

46

47

48

49

50

51

52

53

54

55

56

57

58

59

60 


\section{The Securitization of Residential Rental Revenue Streams in Europe}

\section{ABSTRACT}

This paper analyses the securitization of rental streams, a new investment and finance product introduced in the U.S. in 2013 that enables fundraising from large residential portfolios owned by major investment funds and investment banking. The securities are made up of non-performance loans as well as real estate portfolios of financial entities.

This security gathers rental payments of several residential properties into pools that are tranched by risk levels and marketed to investors with compatible risk profiles. The result is a capital market product with a competitive cost of capital that allows for an increase in indebtedness capacity. This converts it into an optimal product, not only for major investors but also for retail investors and households through multiborrower securitizations.

Thus, the conversion of residential property into an investment asset is a step forward to democratizing finance through the globalization of residential markets, having a positive impact on the efficiency of a basic need product. The positive externalities of this innovative product and its significant success in the U.S., as well as the lack of penetration in the European market, which is characterized by the scarcity of alternative funding channels, are discussed.

Keywords: Property Securitization, REO-to-Rental Securitization, Non-Performance Loans, Alternative Finance, Property Finance, Real Estate Investment, Government Policies.

JEL codes: R30, G02, G18, G14, G32.

\section{INTRODUCTION}

At the end of 2013, a global investment firm launched an innovative finance and investment vehicle that securitized the cash flows originating from leased residential properties. That issue resulted in considerable success and in the development of a new alternative and innovative financing source for real estate activity.

Although after the financial crisis, non-performance loans and foreclosed real estate assets represented a severe concern, today, they are the basis of a desirable new institutional asset class (Fields, 2015) being commercialized through tenders by financial entities. Major investors, mostly from Wall Street, are acquiring portfolios of residential assets (which in recent history had not been part of their investment portfolios), converting them into an institutional asset class. This is a step forward in the globalization of property markets and the improvement of risk sharing (Bank of England, 2014a). 
Residential assets have become an efficient security in terms of risk and return to major investors because of the development of information technologies that have enabled investors to take advantage of scale economies and to manage granularity and the lack of homogeneity of residential assets (Roig, 2015).

Taking into account that housing is a primary need of our society, there is a strong motivation for improving the residential market, and thus, REO-to-Rental securitization could help take a step forward in making the housing market more efficient (Shiller, 2013).

\section{MethodolOGY}

The methodology applied in the study is outlined below.

First, an academic analysis of the European securitization market is performed, as well as a broad overview of the state of the art of the rental housing market and investment property market.

Second, a market study of Real Estate Owned (hereinafter, REOs) and Real Estate Debts (hereinafter, REDs) is carried out to determine both the present framework and future trends. Various financial entities and real estate management companies are examined through interviews and data collection to assess the reality of distressed assets and residential portfolios owned by major investors.

It is introduced the concept of Broker's Price Opinion (hereinafter BPO), which corresponds to the valuation opinion of real estate brokers. Some stakeholders consider that, when determining closing prices, property agents are generally more realistic, quicker, and cheaper than appraisers.

Additionally, the Non-Core Real Estate concept is introduced, which corresponds to those property assets that are either not essential or simply no longer used in a company's business operations, usually serving companies best when extra cash is needed as they can often be sold. In the case of financial entities, these assets correspond, habitually, to distressed properties.

Additionally, the London Interbank Offered Rate (hereinafter, LIBOR), which corresponds to the interest rate participating banks offer to other banks for loans on the London market, is used as the reference index in REO-to-Rental ${ }^{1}$ securitizations and is applied when analyzing the costs of capital spread.

Finally, a Loan-to-Value analysis is provided to identify the evolution and determinants of households' indebtedness; this ratio reflects the weight of the debt over the value of an asset.

$$
\text { LOAN-TO-VALUE }(\text { LTV })=\frac{\text { AGGREGATE LOAN VALUE }}{\text { APPRAISAL VALUE }}
$$

\footnotetext{
${ }^{1}$ Properties owned by a lender, usually a bank after a foreclosure auction. Despite being sold, they are commercialized to rent.
} 
Where:

Aggregate loan value corresponds to the aggregate principal balance(s) of all mortgages on a property.

Appraisal value corresponds to the opinion of the value of real property, that is, the estimated amount for which an asset or liability should exchange on the valuation date between a willing buyer and a willing seller in an arm's length transaction, after proper marketing and in an agreement in which both parties have acted knowledgeably, prudently and without compulsion.

\section{RESIDENTIAL PROPERTY FINANCE AND INVESTMENT IN EUROPE}

\subsection{REAL Estate OWNED PROPERTIES AS AN INVESTMENT ASSET CLASS}

\subsubsection{Introduction to residential investment}

In the current economic context caused by the financial crisis that began in 2007 and by the economic downturn that it triggered, household wealth suffered a great impact, with negative net worth in many homes. For the world's real estate market, events of recent years represented the greatest crisis since the 1930s and had a devastating impact on the wealth of individuals.

Meanwhile, due to the confluence of different factors, such as the turning point in the economic cycle, an environment of interest rates at historic lows, the fall of energy prices, expanding private consumption, the scarcity of efficient alternative investment products and low housing construction, investors' interest in the real estate market has recently been aroused.

This has supposed a recent property price increase, an upward trend that is expected to continue in the future and that has boosted the investment interest in residential property not only by households but also by major investors (e.g., Deloitte, 2015, Eurostat, 2015a). Reinforcing the fact, a considerable increase in institutional investors allocating residential property assets in their portfolios is identified in the U.S. and in European countries, from less than $1 \%$ in 2004 to $6.5 \%$ at the end of 2012 (Molloy and Zarutskie, 2013).

Notwithstanding the above, the financial crisis led to an increase in foreclosure proceedings, resulting in a significant number of empty properties in some regions of Europe, reflecting the imbalance of the European property market. These conditions entail pressure on property prices and difficult recovery in those regions and can lead to an increase in vandalism, crime or the quality of life in a neighborhood.

Moreover, despite the prevailing property culture in Europe prior to the financial crises, high credit standards, the down payment requirement increase and the impact of foreclosures on the society (Cuerpo et al, 2014) marked a turning point, with rental tenure becoming increasingly important; for instance, in $2014,31.1 \%$ of the EU population was living in rental housing (Eurostat, 2015b). The increasing interest of funds in housing investment could be great news if this results in an increase in the offerings of decent rental housing at an affordable price in a safe environment, which is a fundamental need and right. 


\subsubsection{Non-Performance Loans and REOs' Framework in Europe}

The financial crisis dramatically increased the number of non-performing loans resulting in judicial proceedings led by financial institutions to recover the credit or the collateral. This circumstance was found not only in the countries most severely affected by the financial crisis, such as Ireland, where 400,000 households experienced negative equity, Spain, with 500,000 households under eviction threat, or Greece, where 500,000 households faced eviction (Cecohdas, 2014), but also in other countries such as the U.S. where 15 million Americans suffered from negative net worth in their homes (Kroszner and Shiller, 2011), or in the UK where between $7 \%$ and $11 \%$ of owner-occupier mortgagors were in negative equity in the Spring of 2009 (Hellebrandt, 2009).

This resulted in thousands of REDs and REOs held on the balance sheet of financial entities' who conducted tenders of portfolios, drawing the attention of investment banks and funds. Despite the management of REDs and REOs being complex due to illegal occupation of properties, unfinished construction, or auction processes, among others, the current supply and demand imbalance has prompted single-family rental investors to step in and take advantage of market dislocation in regional markets (Mistretta, 2013).

Thus, the interest of Wall Street companies in residential property, stimulated by some government incentives in the U.S. to invest in distressed properties in order to reduce the foreclosure inventory (Reed, 2012), leads to a better link between finance and real estate, which is great news for both industries.

\subsubsection{The vendors of REDs and REOs in Europe}

In 2015, non-core real estate exposure to loans and REOs in the balance sheets of European Banks and Asset Management Agencies (hereinafter, AMA) was approximately $€ 531 \mathrm{bn}$, or $€ 333 \mathrm{bn}$ once loan loss provisions are deducted (net exposure).

Overall, it is estimated that European AMA hold over $45 \%$ of the total gross exposure of non-core real estate, with the remainder under bank ownership, for a total of 51 entities between European Banks and AMAs. From a country perspective, Spain and Italy are expected to lead the pipeline of deals in the coming quarters, taking into account their exposure to non-core real estate assets (Table 01).

Table 01: Gross non-core Real Estate exposure by country in Europe ( $€$ bn)

\begin{tabular}{ccccccccr} 
Ireland & UK & Netherlands & Germany & Portugal & Spain & Italy & Other Europe & Total \\
\hline 64 & 123 & 16 & 26 & 6 & 203 & 67 & 26 & 531 \\
\multicolumn{2}{l}{ Source: Cushman \& Wakefield (2015) } & & & & &
\end{tabular}

The UK and Ireland have reduced their exposure by $€ 27 \mathrm{bn}$ and $€ 27.5 \mathrm{bn}$, respectively, the most in Europe over the past year, followed by Spain and Germany with $€ 16.5 \mathrm{bn}$ and $€ 3.75 \mathrm{bn}$. These countries were the top European vendors of loans and REOs during 2014 and 
2015. Table 02 shows the evolution of REO and RED transactions in Europe between 2012 and 2015.

Table 02: European Loan \& REO closed transactions ( $€ B N)$

\begin{tabular}{cccc}
2012 & 2013 & 2014 & $2015^{*}$ \\
\hline 25 & 32 & 82 & 125 \\
$*$ Real data through & $3 Q 2015,4$ Q forecasted &
\end{tabular}

Source: Cushman \& Wakefield (2015)

In 2015, the most active companies in terms of volume of REO and RED transactions were mainly located in the UK and Ireland (Table 03).

Table 03. Top 5 vendors in 2015 in Europe $(€ M)$

\begin{tabular}{cccccc} 
RBS & Permanent & NAMA & LBG & AVIVA & Other \\
\hline 5,717 & 5,481 & 5,443 & 3,711 & 3,645 & 52,167
\end{tabular}

Source: Cushman \& Wakefield (2015)

\subsubsection{The investors}

The considerable investment momentum in residential properties by investment banks and major funds have transformed REO-to-Rental securitizations into an institutional investment asset in a relatively short period of time. This fact can be explained due to the concurrence of several factors: a lack of investment assets with an appealing risk-return tradeoff, interest rates at historic lows, huge RED and REO portfolio commercializations, property assets below replacement costs, surging rental demand, the upturn of property markets, relatively significant volatility in the stock markets, high price of bonds, tightening of access to credit, and the increase in the cost of capital due to risk premiums, among others.

Table 04 shows the top five investors in Europe during 2015. Additionally, other investors such as Blackstone, Starwood, Deka, BlackRock and TPG also played an important role in the market.

Table 04: Top 5 Investors in Europe in Non-Performance loans or REOs. 2015 (€M)

Top 5 Investors in 2015 in Europe (€M)

\begin{tabular}{ccccc} 
Cerberus & $\begin{array}{c}\text { Deutsche Bank } \\
\text { Apollo }\end{array}$ & $\begin{array}{c}\text { Lone } \\
\text { Star }\end{array}$ & $\begin{array}{c}\text { CarVal / Goldman } \\
\text { Sachs }\end{array}$ & Oaktree \\
\hline $7,686.00$ & $5,481.00$ & $5,443.00$ & $3,711.00$ & $3,645.00$
\end{tabular}

Source: Cushman \& Wakefield (2015)

The huge volume of properties that these investors are managing and that would be managed is great news but also a challenge for the market due to misaligned incentives 
Table 05: Dependence of Europe on banks relative to the USA

\begin{tabular}{crc}
2013 & EU & US \\
\hline Bank balance sheet assets as \% of GDP & $366 \%$ & $78 \%$ \\
Bank lending as a \% of external Long Term Financing & $81 \%$ & $19 \%$ \\
Source: Cummings (2013) &
\end{tabular}

Due to the decline of the property finance of traditional suppliers, real estate companies are obliged to look for alternative sources of finance, and amid a low interest rates scenario in Europe, capital markets, insurance companies and other institutional investors searching for returns have emerged as alternative credit providers. The increase in alternative financing suppliers is generally positive, as there is less dependence on specific lenders (Wass, 2015).

Table 06 shows the substantial increase in alternative financing in the largest European real estate companies; alternative finance when from 10 bn€ in 2009 to 32,8 bn€ in 2014 . These alternative finance sources correspond to medium-term notes, convertible bonds and commercial paper to generate external funding through the capital markets.

Table 06: Liability structure of the top 10 European real estate companies

\begin{tabular}{rcccccc} 
& 2009 & 2010 & 2011 & 2012 & 2013 & 2014 \\
\hline Alternative financing & $46 \%$ & $50 \%$ & $50 \%$ & $60 \%$ & $58 \%$ & $63 \%$ \\
Bank financing & $54 \%$ & $50 \%$ & $50 \%$ & $40 \%$ & $42 \%$ & $37 \%$ \\
Source: Wass, 2015 & & & & & &
\end{tabular}




\section{Present Framework of SeCURITIZATION IN EuROPE}

\subsection{SECURITIZATION}

Securitization corresponds to the process of pooling assets to transform them into a security or bond that will be marketed by shares to investors. Thus, securitization allows risk transfer from one holder to several investors through the commercialization of a pool of assets

Securitization enlarges the scope of target investors, as the risk diversification achieved by combining different assets reduces the overall default rate and enhances asset liquidity. In fact, to attract investors with different investment policies, a security is segmented into tranches with different credit ratings. The most senior tranches are less risky (as investors get paid first) and have lower returns, whereas junior tranches are riskier and carry higher returns.

Securitization allows issuers to finance their investments without convening traditional suppliers (that is, financial entities), and this increase in financial sources leads to more efficient financial markets. Securitizations issued by financial entities allow them to free up their balance sheets for further lending to the real economy without committing large sums of capital resources, resulting in a reduction of financial costs, a broader distribution of risk and the containment of systemic risk (Bank of England, 2014b).

Despite these advantages, there is a problem with property risk securitization considering the difficulties in determining credit ratings due to the heterogeneity of underlying contracts, low credit agency competition, and the tail risks of property assets.

In summary, securitization supports economic growth, increases financial resources and enables issuers and investors to diversify and manage risk. Moreover, it enhances asset liquidity by turning the underlying assets into marketable securities.

\subsubsection{The European Securitization Market}

The years after the financial crisis were particularly severe for the European securitization market, which dropped from $€ 450$ billion in 2006 to $€ 85$ billion in 2014, not only because of uncertainty but also due to new regulatory measures (Hopkin, 2015).

Table 07 compares issuances in the U.S. and EU. The impaired European securitization market (Bank of England, 2014b) can be seen.

Table 07: U.S. and Europe Securitization Issuances 2001 - 2014 (€Billions)

\begin{tabular}{rcccccccccccccc} 
Country $\backslash$ Year & 2001 & 2002 & 2003 & 2004 & 2005 & 2006 & 2007 & 2008 & 2009 & 2010 & 2011 & 2012 & 2013 & 2014 \\
\hline US & 2,308 & 2,593 & 2,915 & 1,957 & 2,651 & 2,456 & 2,081 & 935 & 1,385 & 1,204 & 1,057 & 1,579 & 1,515 & 1,130 \\
EU & 153 & 158 & 217 & 244 & 327 & 481 & 594 & 819 & 424 & 379 & 376 & 253 & 180 & 217 \\
EU vs $U S$ & $6.6 \%$ & $6.1 \%$ & $7.4 \%$ & $12.4 \%$ & $12.3 \%$ & $19.6 \%$ & $28.5 \%$ & $87.6 \%$ & $30.6 \%$ & $31.5 \%$ & $35.6 \%$ & $16.0 \%$ & $11.9 \%$ & $19.2 \%$
\end{tabular}

Source: AFME, 2015

Specifically, the outstanding amount of securitized assets in the EU is about $€ 1,500$ billion, representing $25 \%$ of the U.S. securitization market. Despite the dwindling interest for 
securitization, the issuings maintain low default rates of approximately $1.5 \%$.

The key success factor of the U.S. market is its low dependency on financial entities in terms of financing, unlike what happens in the European market where institutional investors such as pension funds and insurance companies comprise a small share. According to Hill (2015), measures should be implemented to increase the weight of other actors in private financing rather than the banking sector, for instance, encouraging institutional investors. However, some EU regulations such as the Solvency II Directive, which primarily concerns capital requirements of European insurance companies, have also obstructed the securitization market (Standard \& Poor's, 2014). Due to that, the European Commission flexibilized the securitization framework in October 2014.

\subsection{The Securitization of Rental Streams of Residential PROPERTY}

\subsubsection{Product Description}

Financial institutions have tightened credit requirements for property financing as it implies high capital requirements. Therefore, real estate organizations have faced the need to search for alternative finance sources such as setting up a REIT, issuing corporate bonds or crowdfunding.

In this context of a lack of property funding, an innovative product was issued for the first time in November 2013 by a U.S. landlord named 'Invitation Homes', a subsidiary of the investment bank 'Blackstone'. It raised significant interest from investors and, despite the lack of historical data, obtained a high credit qualification from three of the largest rating agencies.

Referring to this new instrument, Rubock, Stark and Lefkowitz from Moody's, Deutsche Bank and JP Morgan, respectively, expected new issuances in the short term, while 2013 Nobel Prize winner Shiller characterized it as a revolution.

Securitization of rental streams corresponds to the combination of different residential property rental payments into pools that are tranched by levels of credit risk and marketed to investors with compatible profiles. Thus, streams of monthly rental incomes provide the basis for payments to bondholders (Edelman et. al, 2014). This feature is one of its main differences with Commercial Mortgage-Backed Securities (hereinafter, CMBS), where streams are originated by mortgage payments.

Another idiosyncrasy of the securitization of residential properties' rental streams is their granularity, as the underlying properties are located in different neighborhoods and regions. Moreover, in REO-to-Rental securitizations, the main risk is the ability to rent residential properties, while CMBS corresponds to debtors' creditworthiness.

Rental streams' securitization key factors are financial planning, credit qualification, investors' guarantees in case of bankruptcy, bond maturity, cost of capital and the collateral features. 


\subsubsection{Forecasting Future Cash Flows}

Potential investors in REO-to-Rental securitizations would be concerned with forecasting expected future cash flows of a portfolio, which will be determined by several factors such as rental levels, delinquency rates, vacancy rates, expense ratios, rental yields, releasing periods or market performance.

For instance, referring to Invitation Homes' first securitization in which average property values were $\$ 199,205$ in 2013 , net cash flows amounted to $\$ 9,513$ per property on average. These cash flows were more than twice the amount needed to pay down the principal and interest of the issued security (Grow et al., 2015).

Table 08: Average cash flow per property in 2013 of the Invitation Homes' first securitization

\begin{tabular}{lcccccccc}
\hline & $\begin{array}{c}\text { Rental \& } \\
\text { Other } \\
\text { Income }\end{array}$ & Vacancy & $\begin{array}{c}\text { Property } \\
\text { Management } \\
\text { Fee }\end{array}$ & $\begin{array}{c}\text { Community } \\
\text { Fees, Insurance, } \\
\text { Taxes }\end{array}$ & Marketing & CAPEX & $\begin{array}{c}\text { Repair }- \\
\text { Maintenance }\end{array}$ & $\begin{array}{c}\text { Net } \\
\text { Cash } \\
\text { Flow }\end{array}$ \\
\hline Cash Flow & 15,881 & 945 & 888 & 2,522 & 350 & 450 & 1,213 & 9,513 \\
\hline$\%$ of Rent & $100.0 \%$ & $6.0 \%$ & $5.6 \%$ & $15.9 \%$ & $2.2 \%$ & $2.8 \%$ & $7.6 \%$ & $59.9 \%$ \\
\hline
\end{tabular}

Source: Moody’s Investors Services Report (2013)

\subsubsection{Qualification}

A key factor to be considered prior to issuing securities is to the security qualification that will be assigned by rating agencies (not only the Big Three, that is Moody's, Fitch and S\&P, but also others such as Kroll, DBRS or Morningstar agencies), as it will enable them to be attractive to pension funds and life insurance (Pierson, 2014).

Rating agencies have a two-fold perspective. Existing securitizations have been significantly well-qualified, but at the same time, they identify some concerns for consideration.

On the one hand, rating agencies are concerned with the lack of historical data that hampers cash flow forecasting, assessment of vacancy rates, rental yields, re-leasing periods and rent levels; the use of broker price opinions (BPOs) instead of full appraisals also raises doubts about collateral values. Another issue is the professionalism of property managers in terms of their ability to set appropriate rental levels, navigate local laws and ordinances pertaining to rentals, conduct proper rent collection, evict tenants in a timely manner, quickly re-lease properties and conduct property maintenance, among other things. Finally, significant concentrations of properties in certain regions can lead to stress price sales (Fitch Ratings, 2013, S\&P, 2014, Pierson, 2014).

On the other hand, some strengths are identified, such as issuers' experience in securitization markets, partnerships with large residential property management companies or first lien priority for bondholders as a guarantee in case of default (Moody's, 2013). Moreover, rating agencies endow value to diversification as it improves cross collateralization and cross default. For example, Invitation Homes securitized homes are located in 18 different 
metropolitan areas distributed among five different U.S. states.

The outcome of the first REO-to-Rental securitization was triple-A for the first and biggest tranche by Moody's Investor Services, Kroll Bond Ratings and Morningstar agencies, despite Standard \& Poor's being less positive. It is also remarkable that issuings carried out by American Homes 4 Rent or Colony American Homes also obtained great qualifications (triple-A for their first tranches) (Kroll Bond Rating Agency, 2014).

\subsubsection{Maturity of bonds}

Bonds resulting from securitizations are usually structured with a 2- to 10-year maturity. Despite the first issuing of REO-to-Rental securitization having a 2-year bond maturity, recently, some bonds have been issued by American Homes 4 Rent with a 10-year maturity.

Moreover, although the first deals were structured to be amortized bonds at maturity, recent deals have been designed as interest-only loans. Additionally, bondholders can agree to lengthen the terms of the deal, providing the borrower with more time for loan repayment to avoid refinancing or default.

\subsubsection{Issuer and bondholder profitability}

From the investor's perspective, REO-to-Rental securitization is considered as a complex instrument that, unlike direct property investment, permits owners to overcome part of the inefficiencies of the real estate market resulting from lack of diversification, lack of homogeneity of the underlying asset, lack of liquidity, transaction costs, and the specific risk of smaller-scale investors (e.g., Roig, 2015).

Both major investors and households can benefit from this innovative product, as its relatively small correlation with stock and bond markets allows the optimization of investment portfolios (Seiler, Webb, and Myer, 1999, Fernandez et al., 2012). Because realestate markets represent such a high proportion of the world's market wealth, it is inconceivable to achieve market beta on a portfolio not including real-estate assets.

Furthermore, a premium of 150 basis points (hereinafter, bps) over traditional CMBS Bonds was forecasted; however, significant demand on first tranches (between 47 and $60 \%$ of the total mortgage amount, Table 09), resulted in a lower cost of capital.

Table 09: Examples of REO-to-Rental Securitizations Premiums by Tranches - bps

\begin{tabular}{|c|c|c|c|c|c|c|c|c|}
\hline \multirow[b]{2}{*}{ Issuer } & \multirow[b]{2}{*}{$\begin{array}{c}\text { Mortgage } \\
\text { Amount (M\$) }\end{array}$} & \multirow[b]{2}{*}{ Date } & \multicolumn{6}{|c|}{ Libor (basis points) } \\
\hline & & & $\begin{array}{c}1^{\text {st }} \\
\text { tranche }\end{array}$ & $\begin{array}{c}2^{\text {nd }} \\
\text { tranche }\end{array}$ & $\begin{array}{c}3^{\text {rd }} \\
\text { tranche }\end{array}$ & $\begin{array}{c}4^{\text {th }} \\
\text { tranche }\end{array}$ & $\begin{array}{c}5^{\text {th }} \\
\text { tranche }\end{array}$ & $\begin{array}{c}6^{\text {th }} \\
\text { tranche }\end{array}$ \\
\hline Invitation Homes & 994 & Apr-14 & 100 & 150 & 210 & 260 & - & - \\
\hline ARP & 342 & Aug-14 & 110 & 175 & 235 & 300 & 392 & 442 \\
\hline PR & 473 & Aug-14 & 110 & 190 & 225 & 275 & 415 & 470 \\
\hline $\mathrm{B} 2 \mathrm{R}$ & 230 & Oct- 15 & 115 & 165 & 195 & 250 & 350 & - \\
\hline
\end{tabular}

Source: Prepared by the author. 
Where:

- ARP, corresponds to American Residential Properties,

- PR, corresponds to Progress Residential,

- $\quad$ B2R, corresponds to B2R Finance

From the perspective of an issuer, a net yield of $12 \%$ on average is targeted, including both rental returns and price appreciation (Pierson, 2014). However, in the European market, interest in acquiring non-performing loans or REO portfolios is increasing, resulting in residential price increases and declining yields.

With this scenario, indebtedness is attractive in order to improve the Return-over-Equity ratio (Goodman, 2014).

\subsubsection{Alternative Financing Source: Cost of Capital and Loan-to-Value}

As discussed earlier, with a cost of capital lower than traditional funding sources, REOto-Rental securitization is an efficient alternative funding channel allowing the development of a competitive advantage from industry competitors; for instance, the cost of capital of Invitation Homes in 2013 was less than half of the finance cost of an average household.

Moreover, it enhances debt capacity, enabling issuers to reduce equity approximately $25 \%$, therefore improving investment yields through financial leverage and creating a competitive advantage compared to those that are only financed through traditional sources and that do not reach such Loan-to-Value ratios (Corkery, 2014, Layton, 2015).

Although this innovative product was originally oriented towards major landlords, multiborrower securitizations have now become a reality in the U.S. markets and they are humanizing markets by transferring their advantages to society.

\subsubsection{Risks}

According to the Basel Committee on Banking Supervision and the Board of the International Organization of Securities Commissions (2015), criteria for risk assessment of asset securitizations are mapped into three types of risk: asset risk relating to the underlying asset pool, transparency around the securitization structure and the governance of key parties to the securitization process. In the particular case of Reo-to-Rental securitization, according to Standard \& Poor's (2014), its major risks depend on (i) operational risk, (ii) the property manager pool and (iii) scarcity of historical data, which hinder the predictability of rental payments.

It is important to note that bondholders have various guarantees to recover their investment such as a first lien and derivative instruments to hedge bondholders' future payments (Pierson, 2014). Moreover, prepayment risk, which refers to the risk of receiving all or part of the principal of the underlying debt before it is due, is managed with penalty impositions (Goodman, 2014).

Furthermore, solvency risk is fairly limited, considering the positive net cash flows that, in severely stressed scenarios, could follow to fulfill the instrument obligations. Finally, 
liquidity risk depends on the quality of properties and rental management instead of the solvency of debtors, which is usually appreciated.

\subsubsection{Alignment between a Primary Need Asset and Home-Owner Interests}

Residential asset portfolios are characterized by scarce homogeneity and significant granularity that hamper efficient management of property owners, even more considering a large short-term investment (Edelman et al, 2014). However, large portfolios entail advantages to society such as an increase in rental housing supply, or to landlords themselves due to scale economies.

On the one hand, there is a significant risk of property oblivion and neglect that can lead to poor conditions of habitability. In this regard, national and local governments and the industry itself should ensure a minimum property quality and management services and protect tenants from abusive terms in lease contracts or from discrimination.

Therefore, being able to consolidate property portfolios and to offer a minimum quality is a challenge for landlords as, according to Takano (2015), some concerns exist regarding the capacity of operators to properly manage a great number of residential portfolios. Along these lines, Call et al. (2014) provided evidence about tenants' difficulties communicating their concerns to the homeowners of Invitation Homes.

Moving on to other issues, the allocation of residential property in portfolios of institutional investors can lead to a volatility increase in capital and lease prices (Molloy and Zarutskie, 2013) emphasized by actions of landlords, new players with access to cheaper funds, high buying power, and portfolios that are over-concentrated in specific regions.

In summary, regulators need to pay close attention to major investors to protect consumers, ensure healthy housing markets, and limit risks to tenants, neighborhoods, and financial markets while trying to align the different stakeholders' incentives.

\subsubsection{In-House Staff: Principal-Agent Issue}

Through the consolidation of residential property as an institutional asset, rental yields would be the basis for the investment feasibility at the expense of capital gains, so efficient operations management would be the key to optimizing the portfolio profitability. Moreover, residential portfolio performance would be highly correlated with operative efficiency, more than other portfolio classes (commercials, for instance, that involve less complex management) (Terzuoli, 2013).

Based on the foregoing, joint ventures between landlords and real estate service companies would be determinant in the long term. However, landlords should retain control over strategic tasks in order to manage the principal-agent problem that boosts conflict of interests and asymmetric information.

Service providers such as asset management companies should intervene in tasks like property inspections, CAPEX analysis, rental commercialization, dwelling renovation and supplying information technologies; the latter is a key success factor when managing granular portfolios like remote technologies, smartphone apps for rent payments or maintenance requests, easing property management while also providing a flow of data (Call 
et al., 2014).

\subsubsection{CAPEX}

Dwelling renovations, repairs and property maintenance investment analysis are key factors to optimize profitability of residential portfolios as they involve time and CAPEX, two factors that considerably affect portfolio yields. Therefore, the allocation of optimal capital expenditures would be a critical factor.

The average expense per dwelling would depend on the landlord strategy and the type of portfolio. While some landlords, such as American Homes 4 Rent, spend between 5 and $8 \%$ of the property value to refinish a property for rent, others like Colony American Homes or Blackstone spend between 10 and 25\% (Pierson, 2014).

\subsection{REAL CASES}

Invitation Homes, a subsidiary of the investment bank Blackstone, was the precursor of securitization of rental streams, and it had to overcome the difficulties encountered during the issuing process. Despite not being its original idea, the need to increase investors' guarantees led Invitation Homes to constitute a mortgage converted into a security in which investors invest to receive coupons corresponding to monthly rental cash payments. Despite extra costs that are faced when mortgaging assets, this additional administrative cost is worthwhile as it enhances investors' confidence (Tempkin, 2013).

Since the first issuance in November 2013, 17 REO-to-Rental securitizations with a total amount of $\$ 12,079$ million of deals backed by rental payments of 140,297 dwellings were identified. Seven of those offerings were issued by Invitation Homes totaling \$5,346 million, which represents $44 \%$ of the total market amount, while American Homes 4 Rent launched five issuings representing $\$ 2,530$ million (Table 10).

Table 10: REO-to-Rental Securitizations Issuings (million \$)

\begin{tabular}{llccc}
\hline Date & Issuer & $\begin{array}{c}\text { Mortgage } \\
\text { Amount }\end{array}$ & $\begin{array}{c}\text { Number of } \\
\text { Homes }\end{array}$ & $\begin{array}{c}\text { Mortgage per } \\
\text { Unit }\end{array}$ \\
\hline Oct-13 & IH & 479 & 3,207 & 149,361 \\
\hline Feb-14 & CAH & 514 & 3,399 & 151,221 \\
\hline Apr-14 & AH4R & 483 & 3,871 & 124,696 \\
\hline Apr-14 & IH & 994 & 6,473 & 153,561 \\
\hline Jun-14 & CAH & 559 & 3,727 & 149,987 \\
\hline Jul-14 & SB & 313 & 3,089 & 101,327 \\
\hline Jul-14 & IH & 720 & 3,750 & 192,000 \\
\hline Aug-14 & ARP & 342 & 2,880 & 118,750 \\
\hline Aug-14 & AH4R & 488 & 3,871 & 126,066 \\
\hline Aug-14 & PR & 473 & 3,142 & 150,573 \\
\hline Oct-14 & IH & 775 & 4,048 & 191,453 \\
\hline Nov-14 & AH4R & 528 & 3,736 & 141,334 \\
\hline
\end{tabular}


Where:

- IH corresponds to Invitation Homes

- SB corresponds to Silver Bay Realty

- SWAY corresponds to Starwood Waypoint

- B2R corresponds to B2R Finance

- AH4R corresponds to American Homes 4 Rent
- CAH corresponds to Colony American Homes

- ARP corresponds to American Residential

- PR corresponds to Progress Residential

- FKL corresponds to FirstKey Lending

It is important to highlight that, although several issuances have been conducted since 2013, they have been focused on the U.S. market, whereas Europe is still waiting.

\subsection{The DEMOcRATIZATION OF REO-TO-RENTAL SECURITIZATION: MULTIPLE BORROWER SECURITIZATIONS}

Multiborrower securitizations are a step further in rental revenue stream securitizations, as rather than constituting a loan on multiple properties of a single borrower, several mortgages are set up to multiple borrowers over their properties, which are pooled into a security and sold to investors. This development is an effective way to democratize finance, considering that like major landlords, small and medium investors would be able to take advantage of Wall Street investors.

B2R Finance LP and First Key Lending, LLC launched this innovative product in 2015 with significant success in the U.S. market. It was primarily oriented to private property owners with one or several assets valued from $\$ 375,000$ to $\$ 65$ million. However, rating agencies had more difficulties assigning a qualification considering that property owners would have different management capacities that impact cash flows and yields (Grow et al., 2015). 


\section{THE IMPLEMENTATION OF REO - TO - RENTAL SECURITIZATION IN EUROPE AS AN ALTERNATIVE FINANCING SOURCE}

More prudent lending policies of financial entities, driven by significant stock of nonperforming loans and distressed properties as well as increased capital requirements (banks' equity levels increased by approximately 68\% between 2006 and 2013), created the right context to drive new financial sources.

Notwithstanding the above, REO-to-Rental securitization in Europe has not taken off, and despite some work that has been done to boost securitization markets, according to the Basel Committee on Banking Supervision and the Board of International Organization of Securities Commission (2015), additional policies should be implemented, including riskbased frameworks, new collateral regulations to emphasize liquidity, and the review of borrowers' limitations in terms of loan-to-value (LTV) ratios or debt-to-income ratios.

Moreover, harmonization of European securitizations requirements could raise nonbank investor interest, one of Europe's major weaknesses. The Dodd-Frank Act in the USA is an example of an improved regulatory framework through which standardized asset-level information and a reduction of conflicts of interest between issuers of asset-backed securities and investors has been achieved (U.S. Securities and Exchange Commission, 2014).

With REO-to-Rental securitization in Europe, once the free rider problem is solved (that is, the higher costs that Blackstone faced when introducing this new product in the U.S. market), European property owners should seriously consider attracting financial resources through this vehicle, all the more bearing in mind the significant achievement in the U.S. markets.

However, the introduction of REO-to-Rental securitization in Europe cannot be left solely to European landlords but must also involve public institutions, which need to reduce the dependence of European economies on banks. (Haldane, 2013). Governments should encourage the development of alternative funding channels, taking into account that financial development contributes to economic growth (e.g., Gaytan and Ranciere, 2014) and, as homes are a primary need, placing special emphasis on the real estate finance development. Thus, the launch of innovative products such as loan-based-crowdfunding, REITs or REO-to-Rental Securitization is the path to follow to democratize finance (Roig and Soriano, 2015).

\section{The GLOBALIZATION OF RESIDENTIAL MARKETS}

Global markets for residential assets have not been established in any nation because of market inefficiencies (Shiller, 2009) that create a significant lack of risk sharing. However, local residential markets are moving forward to its professionalization and globalization thanks to the introduction of innovative products such as REO-to-Rental securitization, which increased major investors' interest in granular residential assets.

The professionalization of real estate markets is closely correlated with the asset category; office property markets are relatively professionalized compared to residential ones, which suffer the negative impacts of atomization and granularity as well as lack of homogeneity and information. 
Despite some doubts on if the current investment momentum in distressed residential assets in the U.S. and Europe is here to stay, everything suggests that this is not a one-time situation but a consolidating trend of alternative investments in Wall Street (BlackRock, 2014).

\section{CONCLUSIONS}

REO-to-Rental securitization packages rental payments of several residential properties into pools that are tranched by risk levels and marketed to investors with compatible investment profiles. Whereas in mortgage-backed-securities the credit event is based on debtors' creditworthiness, in rental stream securitizations, it is based on landlords' ability to rent their residential assets. These securities allow investors to overcome part of the inefficiencies of real estate markets and to manage risk through diversification.

The securitization of rental streams in Europe has not taken off, despite several issuances in the U.S. since 2013 with significant success where first tranches obtained a credit qualification of triple-A from the majority of the main rating agencies.

In light of its success in the U.S., European landlords, institutions and investors should incentivize REO-to-Rental securitization considering the scarcity of alternative funding channels and the dependence of the EU economy on bank financing. Furthermore, considering its competitive cost of capital and a greater loan-to-value compared to traditional property financing, investors improve their yield through financial leverage and gain a competitive advantage over competitors. Importantly, not only major landlords (to whom this product was first targeted) can benefit from these advantages but also small and medium investors through multiborrower securitization, implemented at the end of 2015.

This competitive funding source also increased funds' interest in housing investment, which would explain the current momentum in residential investment; however, potential growth still exists, bearing in mind that the non-core real estate exposure of loans and REOs in Europe is approximately $€ 531 \mathrm{bn}$.

Another relevant issue is the impact of major landlords in the market and their alignment of interests with tenants, neighborhoods and society. The increase in size and scope of residential property portfolios, which are characterized by lack of homogeneity and granularity, constitutes a significant risk of exceeding the management capabilities of landlords but also has a positive effect on the growth of rental housing supply and the exploitation of scale economies with the use of information technologies.

REO-to-Rental securitization is a step forward towards the democratization of finance through the globalization of the residential market, improving risk sharing for major and retail investors.

\section{References}

AFME (2015). Securitisation Data Report, Q2:2015. Available at: http://goo.gl/jlAZZpa Bank of England (2014a). The Case for a Better Functioning Securitization Market in the European Union. 
Bank of England (2014b). The Impaired EU Securitisation Market: Causes, Roadblocks and how to deal with Them. Available at: http://goo.gl/KPaIas

Basel Committee on Banking Supervision; Board of International Organization of Securities Comission (2015). Criteria for identifiying simple, transparent and comparable securitizations. Bank for International Settlements, OICU - IOSCO. Available at: http://goo.gl/1fgQTn

BlackRock (2014). The Ascent of Real Assets. Gauging Growth and Goals in Institutional Portfolios. Available at: https://goo.gl/25pkx9

Call, R.; Powell, D.; Heck, S. (2014). Blackstone: Atlanta's Newest Landlord. The New Face of the Rental Market. Occupy Our Homes Atlanta. Available at: http://goo.g1/739sL1

Cecohdas (2014). Housing market, financial and social stability in Europe. Economy. Available at: http://goo.gl/rTTB3D

Corkery, M. (2014). Wall Street's New Housing Bonanza. New York Times. Available at: http://goo.gl/RRVz5T

Cuerpo, C.; Kalantaryan, S.; Pontuch, P. (2014). Rental Market Regulation in the European Union. European Comission, Economic Papers 515. Available at: http://goo.gl/GP1ofW

Cummings, C. Alternative finance for SMES and Mid-Market companies; ARES \& CO, Strategy Consulting; 2013. Available at: http://goo.gl/73rInz

Cushman \& Wakefield (2015). European Real Estate Loan Sales Market (Q2 2015). Available at: http://goo.gl/qTrT80

Deloitte (2015). Property Index. Overview of European Residential Markets. Available at: http://goo.gl/zLiyIV

Edelman, S; Gordon, J.; Sanchez, D. (2014). When Wall Street Buys Main Street. The Implications of Single-Family Rental Bonds for Tenants and Houseing Markets.Available at: https://goo.gl/K22sf2

Eurostat (2015a). Housing Price Statistics - House Price Index. Available at: http://goo.gl/c3XKib

Eurostat (2015b). Housing Statistics. Tenure Status. Available at: http://goo.gl/P0j2XV

Fernandez, J.; Llovera, F. J.; Roig, J. (2012). Los REITs españoles como vehículo de inversión y financiación de la actividad inmobiliaria: las SOCIMI. Intangible Capital, 8 (2), pp. 308-363.

Fields, D. (2015). Distressed-as-Desirable Assets: Post-Crisis Reprensentations of Housing. RC21 International Conference on "The Ideal City: between myth and reality. Available at: http://goo.gl/TJNH7b

Fitch Ratings (2013). Too Soon for 'AAA' on Single Family Rental Securitizations. Available at: http://goo.gl/8eCqiq

Gaytan, A., Ranciere, R. (2004). Wealth, financial intermediation and growth.Available at SSRN 860925.

Goodman, L. (2014). Single-Family Securitized Financing: A Blueprint for the Future? Urban Institute Elevate de Debate. Available at: http://goo.gl/67lhFo 
Grow, B.; Singhania, G.; Guo, C. (2015). Issuance of SFR Securitizations Tops \$13 Billion. Morningstar Perspective. Available at: https://goo.gl/BZFT4v

Hellebrandt, T. (2009). The economics and estimation of negative equity. Quarterly Bulletin. Available at: http://goo.gl/ZtjSEP

Hill, J. (2015). Introductory remarks by Commissioner Jonathan Hill at the launch of the Capital Markets Union Action Plan. Available at: http://goo.gl/Idz93b

Mistretta, S. (2013). Institutions Tagged as Fuelling New Property Bubble. Available at: http://goo.gl/xg1HRW

Haldane, A. (2013). How to rehabilitate securitization, IFLR. Disponible en: http://goo.gl/e3x07k

Hopkin (2015). Securitisation in Europe. AFME Finance for Europe. Available at: http://goo.gl/ajDo5g

Kroll Bond Rating Agency (2014). Colony American Homes. Available at: http://goo.gl/sX6yv1

Kroszner, R. S., Shiller, R. J. (2011). Reforming US Financial Markets. MIT Press.

Layton, J. (2015). Single - Family Rental Securitizations. Institute for Real Estate Studies. Available at: http://goo.gl/D6etd8

Molloy, R.; Zarutskie, R. (2013). Business Investor Activity in the Single-FamilyHousing Market. Federal Reserve Notes. Available at: http://goo.gl/pfddgT

Moody's (2013). REO-to-Rental Update: Moody's Issues Guidance on Structuring Risks. Available at: http://goo.gl/u8QtgU

Pierson, M.W. (2014). REO to Rental: The Creation of a New Asset Class and the Transformation of the American Single-Family Landscape. Massachusetts Institute of Technology. Available at: http://goo.gl/dpNBvl

Reed, J. (2012). Obama Launches Reed's REO Pilot Program to Help Fix Housing Market. Available at: http://goo.gl/jI3DuX

Roig, J. (2015). Análisis e inversión en el mercado inmobiliario desde una perspectiva conductual. Universitat Politècnica de Catalunya. Available at: http://goo.gl/ostk8X

Roig, J; Soriano, J. (2015). Crowdfunding de préstamos para PyMEs en España: Un Análisis Empirico. Estudios de Economía Aplicada, Vol. 33 (1), pp. 1-18

Seiler, M.; Webb, J.; Myer, N. (1999). Diversification issues in real estate investment. Journal of Real Estate Literature, 7(2), 163-179.

Shiller, R. J. (2009). The New Financial Order: Risk in the 21st century. Princeton University Press.

Shiller, R.J (2013). Finance and the Good Society. Princeton University Press.

S\&P (2014). S\&P: 3 reasons REO-to-rental bonds are not triple-A. Available at: http://goo.gl/CtPF6F

Takano, M. (2015) Rent on the Rise on Riverside. Housing. Available at: http://goo.gl/mseL2z

Tempkin, A. (2013). REFILE-Blackstone eyes first-ever REO-to-rental securitization. Available at: http://goo.gl/Iusn7N 
Terzuoli, F. (2013). Managing \& Modeling Rental Costs: The Lease-Up, Rent Collection, Delinquencies and Turnover Costs. Single Family Aggregation: The REO-toRental Forum. Available at: http://goo.gl/zgyPYK

U.S. Securities and Exchange Comission (2014). Asset Backed Securities. Available at: https://goo.gl/7JNb3g

Wass, P. (2015). Capital Markets Replace Banks - European Estate Companies Banking on Financing Alternatives. Scope Ratings. Available at: https://goo.gl/cfktQ7 